\title{
Seyahat Bloglarında Yer Alan Destinasyon Rehberlerinde Yeme-Içme Önerileri: Turistler Gerçekten Etkileniyor Mu?
}

\author{
Duran CANKÜL, Hilmi AR ${ }^{*}$
}

Seyahat Bloglarında Yer Alan Destinasyon Rehberlerinde Yeme-Içme Önerileri: Turistler Gerçekten Etkileniyor Mu?

Özet

Araştırma turistlerin seyahat bloglarında yer alan destinasyon rehberlerindeki yeme-içme aktivitelerine ilişkin önerilerden etkilenimleri ile ilgili bir durum değerlendirmesi gerçekleştirmeyi amaçlamaktadır. Bu doğrultuda nitel veri toplama yöntemlerinden görüşme tekniği kullanıımışıı. Veriler çevrimiçi platformda 71 kişiden yarı-yapılandırımış görüşme formu aracılığı ile toplanmıştır. Elde edilen veriler bilgisayar ortamında çözümlenmiş, betimsel analiz ve sayısal analize tabi tutulmuştur. Bulgular turistlerin seyahat bloglarındaki yeme-içme aktivitelerine ilişkin içeriklerin seyahat planlamasına etki ettiğini, bu etkinin ise bloglarda gidilecek destinasyon ile ilgili sunulan bilgilerden kaynaklandığını göstermektedir. Ayrıca, seyahat bloglarındaki görsel içerikler metin içeriklere göre çok daha fazla dikkat çekmektedir. Bunun yanı sıra, seyahat bloglarına yönelik güven algısının değişkenlik gösterebildiği bu hususta kullanıcı yorumla$\mathrm{rl}$, reklam içerikleri, içerik metnin diğer bloglarla örtüşmesi ve abartılı olup olmaması gibi etkenlerin belirleyici olduğu görülmektedir.

Anahtar Kelimeler: Blog, Seyahat Blogları, Destinasyon Rehberi, Yeme-lçme Aktiviteleri
Advice on Eating and Drinking in Destination Guides included in Travel Blogs: Are Tourists Really Affected?

\section{Abstract}

This study aims to conduct a case study of effects of recommendations on eating and drinking activities of travel blogs on tourist by using the interview technique. Opinions of 71 attendants were collected by a semi-structured interview. Data obtained was processed on computer by descriptive analysis. Findings indicate that contents of travel blog on eating and drinking activities influences tourist's travel plans. It was also determined that tourists pay more attention to visual content than texts on these blogs. Moreover, it can be suggested that user trust for these blogs can vary depending on factors such as user comments, advertisements, texts and coherence of these with the other sources and their exaggeration levels.

\section{Giriş}

Key Words: Blog,Travel Blogs, Destination Guide, Eating And Drinking Activities. 
Internet çağı olarak nitelendirilen günümüzde, internet kullanımı gitgide yaygınlaşmaktadır. Sonsuz bilgi kaynağı gözüyle bakılan internet, zamanla insanların her konuda bilgi edinmeye çalıştığı ve bilgisi olduğu durumlarda dahi bilgiyi teyit etme ihtiyacı duyduğu bir veri hazinesi halini almıştır. Bu uçsuz bucaksız veri hazinesinde kaybolmak kaçınılmaz olduğundan internette yer alan platformlar spesifik ilgi alanlarına göre çeşitlenerek gelişmiştir. Öyle ki, sosyal medya ağları, forumlar, bloglar vb. internet platformları ilgi alanlarına göre insanların birçok konuda deneyimlerini, fikirlerini diğer kişilerle paylaşabilmesine ve etkileşim sağlayabilmesine olanak tanımıştır. Kısaca, deneyimlerini paylaşmaktan keyif alan insanlar için "kişiye özel ve ilgi alanı konseptli web sayfaları" olarak tanımlanabilecek bloglar bu doğrultuda ortaya çıkmışır. İnternetin bilgi kaynağı şeklinde hizmet edebilirliğinin gitgide gelişmesi blog platformlarının önemini arttırır hale gelmiştir. Söz konusu blog platformlarında paylaşılan deneyimler, o deneyimi yaşamayı talep etme intimali olan kişiler tarafından deneyimi planlama ve seçme sürecinde kullanılmaktadır. Bakıldığında, turistler için tatmin edici bir turistik deneyim arzulanan, beklenen deneyimin gerçekleşmesiyle mümkün olabilmektedir. Yeme-içme aktivitelerinin günümüzün en önemli seyahat motivasyonlarından biri olduğu düşünüldüğünde yeme-içme davranışına yönelik faaliyetlerin bu noktada beklenen "turistik deneyimin" önemli bir parçası olduğu yadsınamaz bir gerçek olarak karşımıza çıkmaktadır. Potansiyel turistler açııından, yeme-içme ile ilgili aktiviteler özelinde bilinmeyeni keşfetme, beklenen deneyime hizmet edebilecek nitelikte tavsiyeleri hali hazırda o destinasyonda yeme-içme aktivitelerinde bulunmuş kişilerden edinme isteği işte bu noktada seyahat bloglarını ön plana çıkarmaktadır. Potansiyel turistlerin ziyaret etmeyi planladıkları destinasyonu daha önce deneyimlemiş ve o mahalde ne yenip ne içileceğine ilişkin metin ve görsel halinde içerik sunan bloglara yaklaşımı ise bir merak konusudur. Seyahat bloglarında sıkça yer verilen "seyahat rehberi" veya "destinasyon rehberi" olarak nitelendirilebilecek ve destinasyonlar özelinde nerede ne yenir ne içiliri ifade eden içeriklerin potansiyel turistlere olan etkisine yönelik literatürde hali hazırda yer alan bir çalışma bulunmamaktadır. Oysa, seyahat etkinliğinde yeme-içme aktiviteleri temel aktiviteler olarak düşünülebilecek unsurlardır. Araştırma, bu doğrultuda günümüzde popülerliği giderek artan seyahat bloglarındaki seyahat deneyimlerinde yer alan yeme-içme aktivitelerine yönelik tavsiyelerden potansiyel tüketicilerin gerçekten etkilenip etkilenmediğine yönelik bir durum değerlendirmesi gerçekleştirmeyi hedeflemesi bakımından önem arz etmektedir.

\section{Kavramsal Çerçeve}

Internet uygulamaları, bilgiye ulaşımı daha kolay hale getirmiş ve ülkesel sınıları ortadan kaldırmışıı. İnternet uygulamaları ve kullanımı her geçen gün hızlı bir şekilde artış ve önem kazanmıştır (Mathews, Bianchi, Perks ve Healy, 2016, s. 820). Son yıllarda ise internet siteleri, kullanıcı merkezli yeni internet uygulamalarının gelişimi sayesinde daha katıımc, interaktif bir hal almışıı (Leung, Bai ve Stahura, 2015, s. 147). Bu durum yeni iletişim kanallarının ve platformlarının ortaya çıkmasına neden olmuştur. Bu uygulamalardan biri de sosyal medyadır. (Budden, Anthony, Budden ve Jones, 2007, s. 147; Leeflang, Verhoef, Dahlström ve Freundt, 2014, s. 1). Sosyal medya, insanların ürettikleri bilgileri paylaşabilmelerine, tartışabilmelerine, güncelleyebilmelerine, yaşadık- 
ları deneyimleri aktarabilmelerine, etkin bir iletişim içerisinde bulunabilmelerine fırsat veren kitle iletişim aracı olarak ortaya çıkmıştır (Leung, Law, Hoof ve Buhalis, 2013; Zeng ve Gerritsen, 2014; Nezakati, vd. 2015, s. 120; Kuric, 2016, s. 41; Capatina, Micu, Micu, Bouzaabia ve Bouzaabia, 2017, s. 2; Sotiriadis, 2017, s. 179).

Kaplan ve Haenlein (2010, s. 61) sosyal medya kavramını “Web 2.0’ın üzerine ideolojik ve teknolojik yaklaşımlarla inşa edilmiş, kullanıcı tarafından içerik oluşturulmasına ve bu içeriklerin başkalarıyla paylaşılmasına olanak tanıyan internet temelli bir takım uygulamalar" şeklinde tanımlamaktadır. Budden vd. (2007) ve Leeflang vd. (2014) ise sosyal medyayı, kullanıcılar tarafından oluşturulan içeriklerde insanların bilgi alışverişinde bulundukları, iletişime geçtikleri, etkileşimde bulundukları ve eğlenceli vakit geçirdikleri sanal ortamlar olarak ifade etmektedir. Sosyal medya bloglar, forumlar, Facebook, Linkedın vb. sosyal ağlar sürekli gelişen ve kullanıılarının hem paylaşımcı hem de mesajların hedefi olduğu ve viral potansiyeli taşıyan farklı çevrimiçi platformlardır (Capatina, vd. 2017, s. 2). Etkileşimli platformlar oluşturmak için kullanıcılar mobil ve web tabanlı teknolojileri kullanmaktadır. (Kietzmann, Hermkens, McCarthy ve Silvestre, 2011, s. 241-242). Bu platformlardaki kullanıc sayısı ile ilgili şekil 1'deki istatistikler kullanıcı sayısında her geçen yıl ciddi bir artış olduğunu göstermektedir.

Şekil 1. Dünyada Sosyal Medya Kullanıcı İstatistikleri 2010-2021

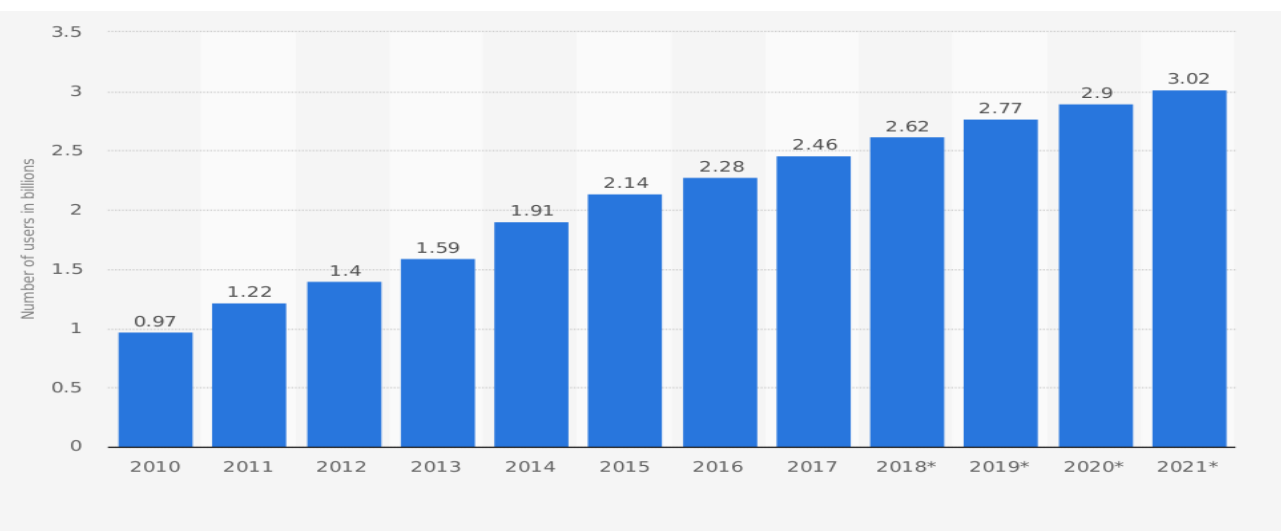

Kaynak: Statista, 2018

Şekil 1'e bakıldığında 2010 yılında dünyada 1 milyara yakın sosyal medya kullanıcısı bulunurken bu rakamın 2017 yılında 2.46 milyara yükseldiği görülmektedir. 2021 yılına kadar dünyada 3 milyar insanın sosyal medya kullanıcısı olması beklenmektedir. 2017 yılı itibariyle dünya nüfusunun yaklaşık 7,6 milyar olduğu düşünüldüğünde günümüzde dünya üzerindeki nüfusun yaklaşık \%31'inin sosyal medya platformlarının kullanıcısı olduğu söylenebilir. Türkiye'de de internet ve sosyal medya kullanıcıları ile ilgili rakamlar dikkat çekicidir. 2017 dijital istatistik sonuçlarına göre Türkiye'de toplamda 48 milyon sosyal medya kullanıcısı bulunmaktadır. Bu rakam ülkenin \%60'lık dilimine denk gelmektedir. Zamansal açıdan irdelendiğinde Türkiye'de internet kullanımı bilgisayar 
veya tablette günlük ortalama 6 saat 46 dakika; telefonda 2 saat 59 dakika; herhangi bir cihazdan sosyal medya kullanımı 3 saat 1 dakika ve televizyon izleme oranı ise 2 saat 14 dakikadır. Türkiye'deki ağ sitelerinin kullanım oranları ise Youtube \%57, Facebook \%56, Instagram \%45 ve Twitter \%44'tür (We are Social, 2017).

Cox, Burgess, Sellitto ve Buultjens (2007) turizm hareketliliği bağlamında bu "yayılan etkinin" seyahat blogları, internet ortamında seyahat ile ilgili değerlendirmeler (yorumlar), fotoğraf ve video paylaşımı ile gerçekleştiğini ifade etmektedir. Cox vd. (2007); Kietzmann vd. (2011) ve Fotis, Buhalis ve Rossides (2012) sosyal medya platformlarının turistlerin tatil planlama süreçlerinin tamamında (tatil öncesi, tatil esnasında ve sonrasında) bilgiye ulaşma, bilgiyi elde etme ve karar verme süreçleri açısından oldukça etkili ve önemli olduğuna dikkat çekmektedir. Bu doğrultuda turistlerin seyahat planlama sürecinde sosyal medyanın etkisine değinen Buhalis ve Law (2008) turistlerin bilgi ve iletişim teknolojilerinden her zaman etkilendiğini teknolojik yeniliklerin beraberinde yeni iletişim kanallarının ve platformların ortaya çıkmasını sağladığını bu durumun turistlerin seyahat planlaması ve seyahat ile ilgili ürünleri tüketiş şeklini tamamen değiştirdiğini belirtmektedir.

Sirakaya ve Woodside (2005) turistlerin tatil seyahatiyle ilgili satın alımlarının, tatil seyahat ürün ve hizmetlerinin bütünleşik ve deneyimsel doğası nedeniyle karmaşık olduğundan turistlerin seyahatleri ile ilgili satın alımlarının yüksek riskler içerdiğini dolayısı ile seyahat öncesinde kapsamlı bir bilgi araştırması yapılması gerektiğini ifade etmektedir.

Seyahat planlama sürecinde sosyal medya araçları, turistlere diğer turistlerin yaşadıkları deneyimlere "örnek ve nihai bir bilgi kaynağı" olarak ulaşabilmelerine imkân tanıması bakımından önemli bir rol üstlenmektedir ve turistler için önemli bilgi kaynağı (Chung ve Buhalis 2008; Kietzmann vd. 2011, s. 241-242), tüketiciler, işletmeler ve pazarlamacılar için ise etkili bir pazarlama kanalı olarak giderek daha fazla tanınmaktadır (Dellarocas 2003; Chung ve Buhalis 2008; Kietzmann vd. 2011; Tiago ve Verissimo 2014; Surugiu ve Surugiu, 2015; Kannan ve Li, 2017).

Çevrimiçi platformlardaki turist yorumları potansiyel turistlerin karar verme sürecinde önemli bir etkendir. Bu konudaki araştırmalar çevrimiçi değerlendirmeler ve yorumların tüketicilerin bilinçli ve bilgili bir biçimde isabetli kararlar verebilmesine yardımcı olduğunu göstermektedir (Chung ve Buhalis, 2008; Sparks ve Browning, 2011; Fotis vd. 2012).

Sosyal medya, turistlerin ziyaret etmeyi düşündügü destinasyonu deneyimlemiş kişilere ulaşma imkânı sunması ve destinasyonlar hakkında bilgi edinebilmeyi mümkün kılması sayesinde tur planlama sürecini yeni bir boyuta taşımıştır. Potansiyel turistler sosyal medya platformlarını kullanarak "birinci ağızdan" bilgi toplayabilmekte ve bir destinasyon veya deneyim ile ilgili karar alabilmektedir. Bu kapsamda, turistlerin deneyim ve anı paylaşımı gerçekleştirdiği bloglar, kişisel internet siteleri vb. çevrimiçi platformlar bilgi toplama aracı olarak kullanılmaktadır. Blog içerikleri genellikle o destinasyonu deneyimlemiş kişilerin görüşleri ve algıladıkları otantik deneyim ile oluşturulmaktadır (Kiralova ve Pavliceka, 2015, s. 359). Bloglar belirli bir ülke veya bölgenin pazarlama faaliyetlerini olumlu yönde artırma potansiyeline sahiptir (Cox vd. 2007). 
Bloggerlar, genellikle seyahat deneyimi hikâyelerini "kendilerinin kelimeleriyle" özgün bir şekilde yorumlayarak aktarmaktadır. Bu durum deneyimin pek de üzerinde durulmayan hazsal hem de öznel boyutlarını farklı bir yol ile anlayabilmeyi mümkün kılmaktadır (Carù ve Cova, 2008).

Günümüzde, seyahat blogları tüketici tercihlerinde oldukça etkili olmaktadır. Dolayısı ile tüm turizm işletmeleri yöneticilerinin, özellikle önde gelen seyahat bloglarındaki kendi ürünleri ile ilgili tüketici yorumlarını göz önünde bulundurması ve dikkate alması başarılı olmaları açısından önemlidir (Zehrer, Crotts ve Magnini, 2011, s. 108).

illgili alan yazında yapılan çalışmalar incelendiğinde turistler için seyahat bloglarının etkisi daha net görülmektedir.

Pan, MacLaurin ve Crotts (2007) seyahat bloglarının turistler için gidilecek bölge ile ilgili önceki deneyimleri öğrenme ve gezilecek yerler veya restoranlar hakkında bilgi elde etme açısından oldukça uygun bir yol olduğunu dile getirmektedir. Ayrıca bilgi teknolojilerinin ilerlemeleri ve bu doğrultuda gittikçe artan seyahat bloglarının, hizmet kalitesini değerlendirmek ve turistlerin genel deneyimlerini iyileştirmek için düşük maliyetli bir yöntem olduğunu vurgulamaktadır.

Volo (2010) bloglarda yer alan bilgilerin veya paylaşımların turistlerin karar verme aşamalarını ve tekrar o bölgeyi ziyaret etme niyetlerini etkileme konusunda daha fazla potansiyele sahip olduğunu ve her zaman deneyimin özünü aktarmasa da turistlerin pazara yönelik bakış açısını yüzeysel olarak yansıtması bakımından önemli bir potansiyel olarak görüldüğünü ifade etmektedir.

Wang (2011) gastronomi bloglarının son yıllarda blog okuyucularına hızlı ve yeni bir çok materyal sağladığını, potansiyel turistlerin davranışsal niyetlerini etkileme potansiyelinin olduğunu ve turizm uygulayıcılarına hedef pazarın algılarını anlayabilme bakımından çevrimiçi platformların önemli bir yol gösterici olabileceğini belirtirken, gastronomi bloglarından hangi faktörlerin okuyucuların yerel yiyecekleri ve içecekleri tatma niyetini tahmin etmede kritik rol oynadığını anlamak için yeterli sayıda yayın olmadığını söylemektedir.

Yazgan (2012)'ye göre bloglar bilgi edinme için önemli bir kaynaktır ve satın alma davranışını pozitif yönde etkilemektedir. Ayrıca bloglardan elde edilen bilgilerin güvenilirliğine duyulan tatmin arttıkça turistik satın alma davranışı eğilimi de artmaktadır.

Sun, Ryan ve Pan (2014) bloggerların paylaştığı görsel ve metin içeriklerinin yalnızca potansiyel ziyaretçiler için değil aynı zamanda ilgili hedef pazarı anlamak isteyen destinasyon pazarlayıcılarına da değerli bilgiler sunduğu belirtmektedir. İçeriklerin metin ve görsel olarak birlikte verildiğinde zengin bir bilgi kaynağı sunduğunu ifade etmektedir.

Chen, Shang ve Li (2014) turizm bloglarındaki içeriklerin bilgi kalitesi ile turistlerin tutumu ve turistlerin destinasyonu ziyaret etmeye yönelik davranışsal niyeti arasındaki ilişkileri belirlemeyi amaçladığı çalışmasında, blog içeriklerinde güvenilirlik, anlaşılabilirlik, ilginçlik boyutları ile kullanıcıların algıladığı haz arasında pozitif bir ilişki olduğunu, ayrıca bu pozitif ilişkinin destinasyonu ziyaret etme niyetine yol açtığını belirtmektedir. 
Kim, Xiang ve Fesenmaier (2015) seyahat planlama sürecinde internet kullanımını araştıran çaış̧malarında seyahat bloglarının daha çok sosyal medya ile meşgul olan genç nesil tarafından seyahat planlama sürecinde kullanıldığını ortaya koymaktadır.

Illgili alan yazındaki az sayıdaki çalışmalar özelinde düşünüldüğünde seyahat bloglarının turistlerin etkilenme bakımından davranışlarını aydınlatmada önemli veri kaynakları olarak dikkat çektiği söylenebilir. Ancak, tüm bunlar ışığında, ilgili alan yazında seyahat bloglarında yer alan seyahat rehberlerinde yeme-içme önerilerine ilişkin içeriklerin potansiyel turistlerin tercihlerine etki edip etmediği ile ilgili gerçekleştirilmiş bir çalışmanın bulunmadığı görülmektedir.

\section{Araştırmanın Yöntemi}

Araştırmada, nitel veri toplama yöntemlerinden yarı-yapılandııımış görüşme tekniği kullanılmıştır. Görüşme formu yanıtlayıcıların konuya ilişkin fikirlerini daha rahat ifade edebilmeleri amacıyla çevrimiçi oluşturulmuştur. Form çevrimiçi olarak yanıtlanacağından katılımcıların demografik özellikleri çoktan seçmeli sorular ile istenmiştir. Oluşturulan görüşme formu sosyal medya platformu olan Facebook'ta yer alan "yemek kültürü" "gastronomi" "seyahat" vb. konuyla bağlantılı temadaki gruplar üzerinden paylaşılmıştır. Hedef kitleden yanıtlayıcılara ulaşabilmek için görüşme formunda ilk olarak "Seyahat planı yapmadan önce seyahat bloglarında gideceğiniz yer ile ilgili bir gezi rehberi okur musunuz? sorusu sorulmuş olup "Evet, OKURUM" ve "Hayır, OKUMAM" seçeneklerinin yer aldığı bu kontrol sorusuna "Hayır, OKUMAM" şeklinde yanıt veren kişilerin görüşmeleri araştırmanın sağııkı bir şekilde gerçekleştirilebilmesi adına sonlandırılarak görüşme formundaki diğer soruları yanıtlamalarına izin verilmemiştir. Katılımcılara konu ile ilgili toplamda 7 açık uçlu soru sorularak konuya ilişkin görüşleri elde edilmeye çalışılmıştır.

Araştırmada amaçlı örnekleme yöntemi kullanılmıştır. Bu yöntem araştırılan olgu ve olayların derinlemesine keşfedilmesine, betimlenmesine ve açıklanmasına katkı sağlamaktadır (Yıldırım ve Şimşek, 2008, s. 107). Bütün nitel araştırmalarda örneklem büyüklüğünün en az on beş olması kabul edilebilir olarak ifade edilmektedir (Mason, 2010, s. 3). Bu kapsamda, 13.11.2017-25.03.2018 tarihlerinde interaktif ortamda hazırlanan çevrimiçi görüşme formu aracılı̆̆ ile 71 adet veri elde edilmiştir. Elde edilen veriler bilgisayar ortamında çözümlenmiş, betimsel analiz ve sayısal analize tabi tutulmuştur. Betimsel analiz de, görüşülen bireylerin görüşlerini çarpıcı bir şekilde yansıtmak amacıyla doğrudan alıntılara sık sık yer verilebilmekte ve elde edilen bulgular düzenlenmiş ve yorumlanmış bir biçimde okuyucuya sunma fırsatını sağlamaktadır. Nitel verinin sayısal analizinde ise sözcüklerin veya cümlelerin hangi sıklıkta tekrar edildiği sayısallaştıılabilmekte ve ortaya çıkan sayısal ifadelerin yorumları daha adil bir biçimde yapılabilmektedir (Yıldııım ve Şimşek, 2008).

\section{Araştırma Bulguları}

Katılımcıların demografik özelliklerini yansıtan Tablo 1'e bakıldığında katılımcıların \%57,7'sinin erkek \%42,3'ünün kadın olduğu görülmektedir. Bununla birlikte, katılımcıların \%60'ı yani önemli bir çoğunluğu 25-34 yaş aralığında yer almaktadır. Görüşmeye katılan katılımcıların \%93'ü Lisans veya 
Lisansüstü eğitim almıştır. Ayrıca, ön lisans eğitim düzeyinin altında eğitim almış bir katılımcı bulunmamaktadır.

Tablo 1. Katılımcıların Demografik Özellikleri

\begin{tabular}{lll}
\hline \hline Cinsiyet & Sıklık & $\%$ \\
\hline Erkek & 30 & 57,7 \\
Kadın & 41 & 42,3 \\
Toplam & 71 & 100 \\
Yaș & $\underline{\text { Sıklık }}$ & $\underline{\%}$ \\
$18-24$ & 6 & 8,5 \\
$25-34$ & 43 & 60,6 \\
$35-44$ & 15 & 21,1 \\
$45-54$ & 3 & 4,2 \\
55 ve üzeri & 4 & 5,6 \\
Toplam & 71 & 100 \\
Eğitim Durumu & $\underline{\text { Sıklık }}$ & $\underline{\%}$ \\
Ön Lisans & 5 & 7 \\
Lisans & 29 & 40,8 \\
Lisansüstü & 37 & 52,2 \\
Toplam & 71 & 100 \\
\hline
\end{tabular}

Seyahat bloglarını ziyaret etme amacı ile ilgili ön plana çıkan tablo 2'deki verilere bakıldığında potansiyel turistlerin öncelikle gidilecek destinasyonla ilgili bilgi edinmek amacıyla bu blogları ziyaret ettiği görülmektedir. Özellikle destinasyon odaklı bilgi arayışı seyahat bloglarını ziyaret etme amacının önemli bir kısmını oluşturmaktadır. Bu yanıtlamaları ise yiyecek içecek işletmeleri ile ilgili bilgi edinmek, seyahat planlaması yapmak ve bir başkasının seyahat deneyimini öğrenmek takip etmektedir. Bakıldığında ön plana çıkan bu yanıtlamalar potansiyel turistlerin seyahat blogları aracılığıyla bilgiye ulaşarak bilinçli bir şekilde seyahat planlaması yapmayı amaçladığını göstermektedir. 
Duran CANKÜL | Hilmi AR

Tablo 2. Seyahat Bloglarını Ziyaret Etme Amacı

\begin{tabular}{lc}
\hline \hline Seyahat bloglarını ziyaret etme amacı & Sıklık \\
\hline Gidilecek destinasyon ile ilgili bilgi edinmek & 31 \\
\hline Yiyecek içecek işletmeleri ile ilgili bilgi edinmek & 18 \\
Seyahat planlaması yapmak & 9 \\
Bir başkasının seyahat deneyimini öğrenmek & 6 \\
Merak & 4 \\
Yeme-içme aktivitelerini planlamak & 4 \\
Eğlenceli aktiviteler planlamak & 2 \\
Tavsiye almak & 2 \\
Hediyelik eşya işletmeleri ile ilgili bilgi almak & 2 \\
Fiyat araştırması & 2 \\
Dinlenebileceğim aktiviteleri öğrenmek & 1 \\
Toplam Veri Kodu & 81
\end{tabular}

Katılımcılardan bazıları seyahat bloglarını ziyaret etme amaçlarını şu şekilde belirtmektedir.

"Seyahate çıkmadan önce seyahate çıkacağım yer hakkında bilgi almak için. Nerde hem uyguna hem kaliteli bir yerde konaklayabilirim, nerde hangi yiyecekleri yiyip içebilirim gibi bilgileri öğrenmek için ziyaret ederim".

"Bilmediğim yerler hakkında daha detaylı bilgi almak, rotaları ortaya çıkarmak, deneyimler hakkında ön bilgi almak".

"Gideceğim yerle ilgi gezilebilecek yerleri ve oradaki yöresel yemekleri öğrenmek için"

Tablo 3'te katılımcıların, seyahat bloglarındaki yeme-içme aktivitelerine ilişkin içeriklerin önemini ifade ettiği yanıtlamalara bakıldığında "yöresel yemekler hakkında bilgi alabilmeyi mümkün kılması", "blog yazarlarının yeme-içme aktivitelerine yönelik öneriler sunması" ve "özellikle gidilmesi gereken mekânları öğrenme" gibi hususlar açısından seyahat bloglarının önem arz ettiğini belirtmişlerdir. 
Tablo 3. Seyahat Bloglarında Yeme-içme Temalı İçeriklerin Önemi

\begin{tabular}{ll}
\hline \hline Yeme-içme temalı içeriklerin önemi & Sıklık \\
\hline Yöresel yemekler hakkında bilgi alabilmeyi mümkün kılar & 14 \\
Blog yazarlarının yeme-içme aktivitelerine yönelik öneriler sunar & 13 \\
Özellikle gidilmesi gereken mekânları öğrenirim & 6 \\
Seyahat deneyimimin riskini azaltmamı sağlar & 4 \\
Özellikle yurtdışı seyahatlerimi planlarken çok dikkate alırım & 4 \\
Fiyat araştırması yapabilmeyi sağlar & 3 \\
Seyahat planlaması yapmak & 3 \\
Zaman yönetimi & 3 \\
Blog yazarlarının deneyimleri & 3 \\
Mekânlarda sunulan hizmet kalitesine yönelik fikir edinebilmeyi sağlar & 2 \\
Otantik mekânlar ile ilgili bilgi sahibi olurum & 2 \\
Yeme-içme aktivitelerine karar vermeye yardımcı olur & 2 \\
Tavsiye almak bakımından önemli & 2 \\
Destinasyona karar verme aşamasında yararlanmam & 2 \\
Mekanların hijyenik unsurları ile ilgili bilgi edinirim & 2 \\
Alternatifleri doğru bir şekilde azaltabilmek & 2 \\
Destinasyonun yeme-içme kültürü farklılılarını öğrenmek & 2 \\
Restoran ve yemek seçimi konusunda bilgilenmek & 2
\end{tabular}

Bazı katılımcılar seyahat planlaması sürecinde seyahat bloglarında yer alan yeme-içme temalı içeriklerin önemini şöyle ifade etmektedir;

"Yemek bir seyahatin iyi veya kötü geçmesini sağlayan en önemli bir etkendir. Ne kadar yediğimiz yemekten zevk alırsak o derece seyahatimizden daha memnun ayrilırı. Ilk defa bir yere gittiğimizde o yere özgü yiyecekleri bilemeyiz ve bu yiyecekleri öğrenmek için seyahat bloglarına başvurulur. O yöreye özgü yiyecekleri en iyi yapan restoranlar cafeler hakkında bilgi almak için yine seyahat bloglarından yardım alırı. Hem öncesinde bilgi alarak zamandan tasarruf yapmamıza hem de seyahatin güzel geçmesi açısından seyahat blogları önem arz etmektedir”. 
"Seyahate katılacak kişilerin vazgeçilmez önceliğini şüphesiz yiyecek içecek konusu oluşturmaktadır. Dolayısıyla bloglarda hemen göze çarpan konu da yiyecek içeceğe ilişkin verilen bilgilerdir. Yiyecek içecek deneyimine ilişkin maceracı bir turist değilseniz ve garantici bir yanınız varsa, bu bilgiler oldukça işinize yarar. Benim açımdan da yiyecek içeceğe ilişkin doğru kanallardan elde edilen bilgiler oldukça önemlidir".

"insanoğlunun en önemli ihtiyaçlarından birisidir. Ama daha da önemlisi gidilecek yerlerde güvenli bir şekilde ne yiyebileceğimiz oraya ait lezzetler nelerdir, sevdiklerimize neler götürebiliriz noktasında çök önemli olduğunu ve seyahat etme nedeni olarak düşünebiliriz".

Katılımcıların, seyahat bloglarındaki yeme-içme temalı içeriklerde öncelikli olarak dikkat ettiği unsurlar ise tablo 4'te fiyat, yöresel yemekler, özel olarak sunulan yemekler, yemeğin lezzetli olduğu fikrini vermesi şeklinde sıralanmaktadır.

Tablo 4. Seyahat Bloglarında Yeme-i̇çme Temalı İçeriklerde Dikkat Edilen Unsurlar

\begin{tabular}{ll}
\hline \hline Yeme-içme temalı içeriklerde dikkat edilen hususlar & Sıklık \\
\hline Fiyat & 21 \\
Yöresel yemekler & 20 \\
Özel olarak sunulan yemekler & 19 \\
Yemeklerin lezzetli olduğu fikrini vermesi & 13 \\
Kullanıcı yorumları & 9 \\
Hijyen & 8 \\
Hizmet kalitesi & 6 \\
Görsel içerik & 6 \\
Reklam amaçlı olmaması & 6 \\
Blog içeriğinin zengin olması & 3 \\
Atmosfer & 3 \\
İnanca uygun yemekler & 2 \\
Objektif bir anlatımı olması & 2 \\
Mekânların konumları ile ilgili bilgi & 2 \\
Güvenilir olması & 2 \\
Yemeklerin çeşitliliği & 1 \\
Yemek tarifi vermesi & 1 \\
Özgün mekânlar & 1 \\
Toplam Veri Kodu & 125 \\
\hline
\end{tabular}

Seyahat bloglarında yer alan nerede ne yenir ne içilir temalı içeriklerde dikkat ettiği hususlarda metin içeriğin detaylı olması gerekliliğini vurgularken görsellerle desteklenmesi gerektiğini belirten bir katılımcı bu durumu şöyle izah etmektedir; 
"Sadece yemeklerin isimlerinin verilmesinin yeterli olmadığını düşünmekteyim. Dolayısıyla daha fazla detaylandırılmış bilgilerin sunulması benim için daha tercih edilebilir. Yiyecekle ilgili metin içeriklerin görsel ile desteklenmesine dikkat ederim. Otantik yiyecek ve içeceklerin verilmesi, bu yiyeceklerin tarihçesinin ortaya konulmasına bakmaktayım".

Reklam barındıran seyahat bloglarıyla ilgili çekincelerini ifade eden bir katılımcı ise dikkat ettiği hususları şöyle ifade etmektedir;

"Reklam olan seyleri sevmiyorum. Samimiyetini kaybetmis oluyor. Yazarak anlatilanlarin fotograflarla desteklenmesine dikkat ediyorum. Bir de tabiki fiyat bilgileri var mı diye bakıyorum".

Tablo 5’e bakıldığında seyahat bloglarındaki yeme içme ile ilgili içeriklerin katılımcıların büyük bir çoğunluğunun yeme-içme ile ilgili aktivitelerine ilişkin seyahat planlamasını etkilediği görülmektedir.

Tablo 5. Seyahat Bloglarındaki Yeme-İçme Aktivitelerinin Seyahat Planlanmasına Etkisi

\begin{tabular}{lc}
\hline \hline $\begin{array}{l}\text { Seyahat bloglarında yer alan içerikler önceden planladığınız seyahat plan- } \\
\text { lamanızdaki yeme-içme aktivitelerini etkiliyor mu? }\end{array}$ \\
\hline Evet & 49 \\
Hayır & 10 \\
Zaman zaman & 12 \\
Toplam & 71 \\
\hline
\end{tabular}

Seyahat bloglarının yer alan nerede ne yenir ne içilir temalı içerikler önceden kurguladığınız seyahat planlamanızdaki yeme-içme aktivitelerine etkisi ile ilgili farklı katılımcı görüşleri şöyledir;

"ilk defa gideceğimiz yer hakkında bir bilgi sahibi değilsek bloglarda yer alan bilgileri dikkate alarak yeme içme planı oluşturabiliriz. Böylelikle seyahatimizi planlandırarak zamanı daha etkili kullanırı. Önceden bir yeme içme planı yapıldıysa bloglardan yer alan yeme içme aktiviteleri merak uyandırdıysa etkilenir ve her iki deneyimi de yaşamak isterim. Merak uyandırmadığı takdirde etkilemez".

"Etkilemiyor. Genellikle seyahat planımdaki güzergahlarda ne yenilip, içileceği konusunda fikir edinmek için kullanıyorum".

"Etkileyebiliyor ama duruma göre değişir tabiki. Arkadaşlardan duyduğumuz mutlaka gidilmeli denilen yerler daha güvenilir gelebiliyor. Bazen bloglardaki bilgiler reklam içerikli de olabiliyor"

"Evet, mutlaka akılda kalıcı bir kaç yiyecek önerisine uymaya calışıorum ve gittiğim yerde tadımını gerçekleştiriyorum". 
"Etkiliyor, farklı bir tat deneyimlemek için seyahat rotamda küçük değişiklikler yapıyorum".

Seyahat bloglarında yer alan nerede ne yenir ne içilir temalı içeriklerin destinasyon tercihine etkisi ile ilgili dikkat çeken bazı görüşleri ise şöyledir;

"Eğer yemek kültürü şehrin kendi tarihi kültürünün önüne geçmişse kesinlikle bu tip destinasyonlari sadece yemek yemek için tercih ettiğimiz oluyor".

"Sadece bazı yerlerde çok az restoran olur blog sahibi de bunlardan birini deneyimlemiştir. Ben de diğerine gidip orayı deneyimlemek isterim. Ama diğer türlü olduğunda neredeyse hiç etkilemiyor canım nerde oturmak istiyorsa oraya geçiyorum".

"Etkiliyor çünkü seyahat edeceğim yerin yiyecek ve içecek açısından. Neleri meşhur buna dikkat ederim ve ona göre nerde ne yiyip ne içeceğimi kafamda belirlerim".

Katılımcılar tablo 6'da çoğunlukla seyahat bloglarındaki yeme-içme aktivitelerine yönelik önerileri "zaman zaman" güvenilir bulduğunu belirtmiştir.

Tablo 6. Seyahat Bloglarındaki Yeme-İçme Aktivitelerinin Güvenilirliği

\begin{tabular}{lc}
\hline \hline $\begin{array}{l}\text { Seyahat bloglarındaki yeme-içme aktivitelerine yönelik önerileri } \\
\text { güvenilir buluyor musunuz? }\end{array}$ & Sıklık \\
\hline Güvenilir buluyorum & 24 \\
Güvenilir bulmuyorum & 7 \\
Zaman zaman & 40 \\
Toplam & 71 \\
\hline
\end{tabular}

Seyahat bloglarının güvenilirliğine ilişkin yargıya varırken farklı blogları değerlendirdiğini ifade eden katılımcı görüşlerinden bazıları şöyledir;

"Duruma göre değiş̧ebiliyor. Blog sahibi bunu bir amatör uğraş ve deneyimlerini paylaşma amacıyla yapıyorsa güvenilir bulabiliyorum. Şayet blog, yazarın nerdeyse tam zamanlı işi haline dönüşmüş ise ve reklam yapıyor izlenimi veriyorsa güvenilirliğini sarsılmış buluyorum. Bunun haricinde yazarın gastronomi bilgisi tavsiyesini ciddiye alıp almamam üzerinde elbette ki önemli bir etkiye sahip".

"Tek kaynak ile sınırlı kalmamaya çabalarım. bir çok kaynaktan elde ettiğim bilgilerin doğruluğunu test etmeye çalışarak, benzer görüşler bulmaya çalışırım.. bilgilerin doğruluğuna kanaat ettiğim takdirde, işlevsel bilgi olarak alarak seyahat planlamalarımda kullanırım”. 
"Her blogun güvenilir olduğunu düşünmüyorum çünkü bazı siteler reklam anlaşmaları kapsamında turistleri maddi gelir sağladıkları yerlere yönlendiriyorlar. Birkaç blog okuyup daha sonra karar vermek daha sağılıkı bir karar olur".

Katılımcıların ifade ettiği görüşlerde seyahat bloglarındaki yeme-içme aktivitelerine yönelik önerilerin güvenilir olup olmadığını belirleyen önemli unsurların ise "daha önce deneyimlemiş kullanıcı yorumlarının olması", "reklam içeriği olmaması", "metnin abartılı olmaması" ve "farklı bloglardaki içeriklerin benzeşik olması" olarak ortaya çıktığı tablo 7'de görülmektedir.

Tablo 7. Seyahat Bloglarındaki Yeme-Içme Aktivitelerinin Güvenilirliğini Etkileyen Unsurlar

\begin{tabular}{lc}
\hline \hline $\begin{array}{l}\text { Seyahat bloglarındaki yeme-içme aktivitelerine yönelik önerilerin güvenilir olup } \\
\text { olmadığını belirleyen unsurlar }\end{array}$ & Sıklık \\
\hline Daha önce deneyimlemiş kullanıcı yorumlarının olması & 18 \\
Reklam içeriği olmaması & 12 \\
Metnin abartılı olmaması & 9 \\
Farklı bloglardaki içeriklerin benzeşik olması & 8 \\
Blog yazarı & 4 \\
Blogun dizaynı & 3 \\
Sponsoru olmaması & 3 \\
Bir süredir takip etmiş olduğum bir blog olması & 3 \\
Görsel içeriğin abartılı olmaması & 3 \\
Kişiye özel bir web sayfasının ötesine geçebilmiş olması & 2 \\
İsmi duyulmuş bir blog olması & 2 \\
Toplam Veri Kodu & 77 \\
\hline
\end{tabular}

Katılımcıların seyahat bloglarında yer alan seyahat rehberlerindeki yeme-içme aktivitelerine yönelik önerileri güvenilir olup olmadığını değerlendirirken dikkat ettiği unsurlara ilişkin çarpıcı bazı ifadeleri ise şöyledir;

"Eğer çok bilindik bir blog ise güvenirim. Daha önce deneyimlerin yorumları yer alıyorsa daha güvenilir geliyor".

"Takip ettiğim sayfalar gerçek gezginlere ait. Reklam alan, ücretsiz gezip yiyip içip konaklama tesisi öneren bloglardan uzak dururum. Yani gezi yazısı değil de gezgin yazısı okurum".

"Genelde reklam içerikli olup olmadığına dikkat ettikten sonra çoğunlukla reklam amaçlı olmadığına gerçekten beni tatmin edecek bir tanıtım mesajı olduğuna kanaat ettik sonra farklı bir kaynakta da benzer içerik ve ifadelerde arayarak aslında doğruluğunu araştırdıktan sonra karar veriyorum".

Tablo 8'de katılımcıların büyük çoğunluğu yeme-içme aktiviteleri ile ilgili içeriklerde görsel içeriklerin metne kıyasla daha çok dikkat çektiğini ifade etmişlerdir. 
Tablo 8. Seyahat Bloglarındaki Yeme-İçme Aktivitelerinin Tasarımı

\begin{tabular}{cc}
\hline \hline $\begin{array}{l}\text { Yeme-içme aktiviteleri ile ilgili içeriklerde metin mi yoksa görsel mi daha } \\
\text { çok dikkat çeker }\end{array}$ & Sıklık \\
\hline Görsel & 55 \\
Metin & 16 \\
Toplam & 71 \\
\hline
\end{tabular}

Katılımcıların seyahat bloglarında yeme-içme aktiviteleri ile ilgili içeriklerde metin mi yoksa görsel mi daha çok dikkatinizi çekmektedir? Sorusuna verdikleri dikkat çekici bazı cevaplar ise şöyledir;

"Görsel yazar tarafından çekilmiş ise dikkate alıım. Onun dışında yazılanlar daha önemlidir".

"Görsel beyne direkt kodlanıyor yani asıl iştah açan kısmı o ama sonuç olarak yine de metin okuyup kara veriyoruz. ikisi de birbirini desteklemeli".

"Görsel daha çok dikkatimi çekmektedir. daha albeni iştah açıı bir özelliği ve ne ile karşılaşacağımızı bilmemiz açısından önemli metinde sadece bilgi var ürünün ne olduğu belli değil”

"ikisinin de önemli olduğunu . görsel ile desteklenmiş bir metnin müşterinin algısında daha kaIıcı olduğunu düşünüyorum. Yiyeceklere ilişkin görsel hafızanın yanında bilişsel hafızanın da dengeli çalıştığını, dolayısıyla tercihlerde her iki faktörün de beraber hareket ettiğini düşünüyorum".

"Görmediğim bilmediğim bir yeri yazıyla bir yere kadar hayal edebilirim eğer o yazı görsellerle desteklenirse fotoğraflarla yolculuğa bile çıkabilirim. Günümüzde görselin önemi tartışılamayacak önemdedir. Bir mekânı çok öven bir blog düşünün. Mekandaki bir yemek tabağından bahsediyor kocaman bir tabak geldi yazdığı zaman ben kendime göre olabilecek kocamanı düşünürüm belki oraya gittiğimde hayal kırıklığına uğrarım ama anlatılan yerde anlattıklarıyla ilgili görsel de varsa yazdıklarını desteklemiş olur".

\section{Sonuç}

Blog platformlarında gezginlerin paylaştığı deneyimler, turistler tarafından seyahat deneyiminin planlanması sürecinde kullanılmaktadır. Arzulanan, beklenen deneyimin gerçekleşmesi her turistin temel beklentisidir. Bu beklentinin önemli bir parçası ise gidilecek destinasyondaki yemeiçme aktiviteleridir. Bununla birlikte, "turistik deneyimin" en önemli motivasyonlarından birinin yeme-içme aktiviteleri olduğu bilinen bir gerçektir. Turistler açısından, beklenen deneyime hizmet edebilecek nitelikte tavsiyeleri hali hazırda o destinasyonda yeme-içme aktivitelerinde bulunmuş kişilerden edinme isteği işte bu noktada seyahat bloglarını ön plana çıkarmaktadır. 
Araştırma sonuçları, potansiyel turistlerin seyahat bloglarını seyahat planlamasına katkı sağlayabilecek olan bilgi edinme sürecinde kullanışlı platformlar olarak gördüğünü göstermektedir. Ayrıca, potansiyel turistlerin seyahat bloglarını yöresel yemekler hakkında sağladığı içerikler, blog yazarlarının yeme-içme aktivitelerine yönelik önerileri ve gidilecek destinasyonda özellikle deneyimlenmesi gereken mekânlara ilişkin bilgiler sunması nedeniyle bu platformları önemli bulduğu söylenebilir. Bu bilgi arayışı sürecinde, gidilecek destinasyon kültürüne has yemekler, destinasyondaki bir mekanda özel olarak sunulan yemekler, blog içeriğinin o destinasyondaki yemeklerin lezzetli olduğu fikrini vermesi ve yemeklerin fiyatına ilişkin bilgi yer alması gibi öğeler turistler tarafından blog içeriklerinde dikkat edilen unsurlardır.

Turistlerin olası yeme-içme deneyimlerini sağlama alarak tatmin olma bakımından risksiz bir seyahat geçirme amacıyla seyahat bloglarını ziyaret ederek bilgi edinmeye çalıştığı söylenebilir. Ancak, seyahat bloglarının güvenilirliğine ilişkin algı değişkenlik göstermektedir. Potansiyel turistlerin seyahat bloglarındaki reklam içerikleri, kullanıcıların yorumları, içerik metninin abartılı olmaması ve diğer bloglar ile fikren benzeşik olması gibi hususları dikkate alarak "güvenilirlik" ile ilgili yargıya vardığı söylenebilir. Bununla birlikte yeme-içme ile ilgili aktivitelere ilişkin içeriklerdeki görsel unsurların çoğunlukla turistlerin ilgisini çektiği tespit edilmiştir.

Araştırma sonuçları turistlerin seyahat planlama süreçlerinde blogların özellikle yeme içme aktivitelerinin planlamasında etkili olduğunu göstermektedir. Araştırma turistlerin seyahat ve yeme içme davranışlarının planlamasını etkileyen sosyal medya araçlarından biri olan blogların kullanımı hakkında literatüre katkı sağlamaktadır. Ayrıca seyahat blogları ile sektörün tüm paydaşlarına bakış açısı sağlamakta ve kılavuz niteliğinde bilgiler sunmaktadır.

\section{Kaynaklar}

Budden, C. B., Anthony, J. F., Budden, M. C., \& Jones, M. A. (2007). Managing the evolution of a revolution: marketing implications of internet media usage among college students. College Teaching Methods \& Styles Journal, 3(3), 1-10.

Buhalis, D., \& Law, R. (2008). Progress in information technology and tourism management: 20 years on and 10 years after the Internet-The state of eTourism research. Tourism management, 29(4), 609-623.

Carù, A., \& Cova, B. (2008). Small versus big stories in framing consumption experiences. Qualitative Market Research: An International Journal, 11(2), 166-176.

Capatina, A., Micu, A., Micu, A. E., Bouzaabia, R., \& Bouzaabia, O. (2017). Country-Based comparison of accommodation brands in social media: ancountry-based comparison of accommodation brands in social media: an fsqca approach. Journal Of Business Research, 1-8. 
Duran CANKÜL | Hilmi AR

Chen, Y. C., Shang, R. A., \& Li, M. J. (2014). The effects of perceived relevance of travel blogs' content on the behavioral intention to visit a tourist destination. Computers in Human Behavior, 30, 787-799.

Chung, J. Y., \& Buhalis, D. (2008). Web 2.0: A Study of Online Travel Community. In P. O'Connor, W. Höpken, \& U. Gretzel (Eds.), Information and communication technologies in tourism 2008 (pp. 70-81). New York, NY: Springer-Wien.

Cox, C., Burgess, S., Sellitto, C., \& Buultjens, J. (2008). Consumer-generated web-based tourism marketing. CRC for Sustainable Tourism.

Dellarocas, C. (2003). The Digitization of word of mouth: promise challenges of online reputation mechanisms. Management Science, 49(10), 1407-1424.

Fotis, J., Buhalis, D. \& Rossides, N. (2012). Social Media Use and Impact During The Holiday Travel Planning Process. In: Fuchs, M. Ricci, F., Cantonini, L. (Eds.), Information and Communication Technologies in Tourism. Springer-Verlag, Vienna, Austria, pp. 13-24.

Kannan, P., \& Li, H. A. (2017). Digital marketing: a framework, review and research agenda. International Journal of Research in Marketing, 22-45.

Kaplan, A. M., \& Haenlein, M. (2010). Users of the world, unite! The challenges and opportunities of Social Media. Business horizons, 53(1), 59-68.

Kietzmann, J. H., Hermkens, K., Mccarthy, I. P., \& Silvestre, B. S. (2011). Social media? get serious! understanding the functional building blocks of social media. Business Horizons, 54(3), 241251.

Kim, H., Xiang, Z., \& Fesenmaier, D. R. (2015). Use of the internet for trip planning: A generational analysis. Journal of Travel \& Tourism Marketing, 32(3), 276-289.

Kiralova, A., \& Pavliceka, A. (2015). Development of Social Media Strategies in Tourism Destination. Procedia-Social and Behavioral Sciences, (175), 358-366.

Kuric, N. (2016). Social Media and Promotion of Tourist Destinations with Negative Country Image. Master Thesis. Switzerland: University of Fribourg.

Leeflang, P., Verhoef, P., Dahlström, P., \& Freundt, T. (2014). Challenges and solutions for marketing in a digital era. European Management Journal, 1-12.

Leung, D., Law, R., Hoof, H. V., \& Buhalis, D. (2013). Social media in tourism and hospitality: a literature review. Journal of Travel \& Tourism Marketing, 30(3), 3-22.

Leung, X. Y., Bai, B., \& Stahura, K. A. (2015). The marketing effectiveness of social media in the hotel industry: A comparison of Facebook and Twitter. Journal of Hospitality \& Tourism Research, 39(2), 147-169. 
Mason, M. (2010). Sample size and saturation in phd studies using qualitative interviews, Forum: Qualitative Social Research, 11(3), 1-19.

Mathews, S., Bianchi, C., Perks, K., \& Healy, M. (2016). Internet marketing capabilities and international market growth. International Business Review, 820-830.

Nezakati, H., Amidi, A., Jusoh, Y. Y., Moghadas, S., Aziz, Y. A., \& Sohrabinezhadtalemi, R. (2015). Review of social media potential on knowledge sharing and collaboration in tourism industry. Procedia-Social and Behavioral Sciences, 120-125.

Pan, B., Maclaurın, T., \& Crotts, J. C. (2007). Travel blogs and the implications for destination marketing. Journal of Travel Research, 46(1), 35-45.

Sirakaya, E., \& Woodside, A. G. (2005). Building and testing theories of decision making by travellers. Tourism management, 26(6), 815-832.

Sparks, B. A., \& Browning, V. (2011). The impact of online reviews on hotel booking intentions and perception of trust. Tourism management, 32(6), 1310-1323.

Sotiriadis, M. D. (2017). Sharing tourism experiences in social media. Emerald Insight, 29(1), 179225.

Sun, M., Ryan, C., \& Pan, S. (2014). Assessing tourists' perceptions and behaviour through photographic and blog analysis: The case of Chinese bloggers and New Zealand holidays. Tourism Management Perspectives, 12, 125-133.

Surugiu, M.-R., \& Surugiu, C. (2015). Heritage tourism entrepreneurship and social media: opportunities and challenges. Procedia - Social and Behavioral Sciences, 75-81.

Statista. (2018). Number of social media users worldwide from 2010 to 2021 (in billions) https://www.statista.com/statistics/278414/number-of-worldwide-social-network-users/.

Tiago, M. M., \& Verissimo, J. C. (2014). Digital marketing and social media: Why bother? Business Horizons, 703-708.

Volo, S. (2010). Bloggers' reported tourist experiences: Their utility as a tourism data source and their effect on prospective tourists. Journal of Vacation Marketing, 16(4), 297-311.

Yazgan, Ş. (2012). Bilgi edinme aracı olarak blogların turistik satın alma davranışına etkisi, Yayınlanmamış Yüksek Lisans Tezi, Adnan Menderes Üniversitesi Sosyal Bilimler Enstitüsü, Turizm İşletmeciliği Anabilim Dalı, Aydın.

Yıldırım, A., Şimşek, H. (2008). Sosyal Bilimlerde Nitel Araştırma Yöntemleri. 6.Baskı, Ankara: Seçkin Yayıncılık. 


\section{Duran CANKÜL | Hilmi AR}

Zehrer, A., Crotts, J. C., \& Magnini, V. P. (2011). The perceived usefulness of blog postings: An extension of the expectancy-disconfirmation paradigm. Tourism Management, 32(1), 106113.

Zeng, B., \& Gerritsen, R. (2014). What do we know about social media in tourism? A review. Tourism Management Perspectives, 27-36.

Wang, H. Y. (2011). Exploring the factors of gastronomy blogs influencing readers' intention to taste. International Journal of Hospitality Management, 30(3), 503-514.

We are Social. (2017). We are Social: https://wearesocial.com/special-reports/digital-in-2017global-overview. 